\title{
Criminal Liability of Political Parties in the General Election of Regional Head in Indonesia
}

\author{
$1^{\text {st }}$ Rahmanu Wijaya \\ Pancasila and Civic Education \\ Department \\ Faculty of Social Sciences and Law \\ Universitas Negeri Surabaya \\ Surabaya, Indonesia \\ rahmanuwijaya@unesa.ac.id
}

\author{
$2^{\text {nd }}$ Jeane E Langkai \\ Public Administration Department \\ Faculty of Social Science \\ Universitas Negeri Manado \\ Manado, Indonesia \\ jeanelangkai@unima.ac.id
}

\author{
$3^{\text {rd }}$ Rusli Abdulrahman \\ Department of Public Administration \\ Faculty of Social Sciences \\ Universitas Negeri Manado \\ Manado,Indonesia
}

\begin{abstract}
Regional Election of 171 (one hundred and seventy-one) regions in Indonesia on 27 June 2018 can be correlated with legislative elections and the election of the President and Vice President of Indonesia in 2019. Candidates for Regional Election are carried by political parties that will later follow the elections in 2019, so that for the Political Party election results are able to show its strength in the region. Regional Election can also be used by Political Parties as one of the ways to achieve victory in General Election 2019. Therefore, Political Parties will mobilize the power and efforts to win in Regional Election. There are many efforts which implemented in negative way and can lead to the criminal act of Regional Election. With regard to the form of associations and administrative structures of Political Parties consisting of centers and regions, this paper traces the criminal liability of political parties to criminal acts of Regional Election.
\end{abstract}

Keywords- Political Parties, Criminal Acts of Regional Election, Criminal Liability

\section{INTRODUCTION}

One of the objectives of the Indonesian state to be realized through a government is the achievement of the people's welfare, such a thing has been formulated by the founders of the nation and expressly stated in the Preamble of the Constitution of the Republic of Indonesia Year 1945 (hereinafter referred to as the 1945 Constitution of the Republic of Indonesia). The meaning of self-government according to Philipus M. Hadjon can be understood by two meanings: on the one hand in the sense of "government function" (governing activity), on the other hand in the sense of "government organization" (collection of government units). The function of this government as a whole consists of various acts of government, only the legislation of the political and judicial authorities by the judges is not included therein. With regard to this understanding, asserting that government has two meanings, namely in a broad sense and in a narrow sense. Governance in the broad sense is called regering or government, that is the execution of the duties of all agencies, institutions, and officers who are entrusted with the authority to achieve state objectives.[1] Concrete meaning of government includes the legislative, executive, and judicial authorities or other state equipments as long as acting for and on behalf of the state. While the government in the narrow sense is called bestuurvoering which includes the organization of functions that perform government duties. The government in this narrow sense relates only to the exercise of executive function alone.

As one form of government in Indonesia, pursuant to the provision of Article 18 paragraph (1) of the 1945 Constitution of Republic of Indonesia established regional government. More specifically, the regions in question are the provinces, districts, and urban areas. So that the structure of the Indonesian government as a whole based on the opening of the fourth alenia of the 1945 Constitution of the Republic of Indonesia is the central government, as a result of the birth of the state of Indonesia. And in Article 18 of the 1945 Constitution there is also regional government, which in Article 18 A of the 1945 Constitution of Republic of Indonesia is determined on the existence of authority relationship between the central government and regional government.

Implementation of regional government as in the Consideration of Law of the Republic of Indonesia Number 23 Year 2014 on Regional Government (Act 23 of 2014), directed to accelerate the realization of community welfare through service improvement, empowerment, and community participation and enhancement of regional competitiveness by taking into account the principle of democracy, equity, justice, and uniqueness of a region in the system of the Unitary State of the Republic of Indonesia. Such a thing illustrates the importance of the role of local government in the effort to realize the state's goal of achieving people's welfare.

One of the factors supporting the success of the role of regional government is the regional head, as according to the provisions of Article 59 paragraph (2) of Law No. 23 of 2014 consists of governors for the province, regents for districts, mayors for urban areas. Concretely, the absolute regional head must be filled by the best people. The filling model, pursuant to the provisions of Article 18 paragraph (4) of the 1945 Constitution of the Republic of Indonesia, shall be implemented by democratically elected.

When examined, the birth of the provisions of Article 18 paragraph (4) of the 1945 Constitution of the Republic of Indonesia is a result of reform. The model of election of regional head desired by the people is to use General 
Election. It is proven that the issuance of the Law of the Republic of Indonesia Number 22 Year 2014 on the Election of Governors, Regents and Mayors governing the mechanism of local elections indirectly through the Regional People's Legislative Assembly has received wide rejection by the people.

Implementation of General Elections as one of the indicators of a democratic country, it can also harm democracy itself. This is due to fraud committed by parties related to the election, the worst conditions as disclosed by Joseph Deckert, Mikhail Myagkov, and Peter C. Ordeshook as a means of corrupt regimes to seek democratic legitimacy.[2]

In this regard, the holding of an election as well as the General Election which is included in the election law regime is needed a rule of the game to be able to support the implementation is really running democratically, in line with those requirements in Law No. 1 of 2015 on Stipulation Perpu No. 1/2014 On the Election of Governor, Regent, and Mayor Become Law, Law RI Number 8 Year 2015, and Law of RI Number 10 Year 2016 About The Second Amendment of Law Number 1 Year 2015 has mentioned various kinds of criminal acts of General Election which is directed to the subject -the subject matter concerning the holding of elections.

With regard to the implementation of the 2018 Regional Head General Election which consisted of 17 Provinces, 39 Municipalities, and 115 Regencies, emphasizing the important role of the Politic Party.[3] All candidates for regional head in Regional Election are carried by political party or coalition of political party. Faced with this condition, it can be said that political party is the entrance for every person who want to run to become head of region. With regard to the position of political parties as one of the subjects having an important role in the General Election and the types of criminal acts of Regional Election (Regional Election) in the election law package, the problems in this study can be formulated with the question "Can political parties be subject to criminal liability for criminal acts of regional head election?"

\section{RESEARCH METHODS}

This research is a legal research, in conducting legal research conducted steps: (1) identifying legal facts and eliminating the things that are not relevant to determine the legal issues to be solved; (2) the collection of legal materials deemed to have relevance, as well as non-legal materials; (3) to have been subject to legal issues filed on the basis of materials already collected; (4) drawing conclusions in the form of arguments that address legal issues; and (5) provide prescriptions based on arguments that have been built in conclusions. These steps are in accordance with the character of legal science as a prescriptive and applied science.[4]

\section{RESUlTS AND DISCUSSION}

With regard to the formulation of the problem which essentially wants to examine whether or not a political party is subject to criminal liability, in this section it is first described on a political party as a criminal law subject. This description is intended to discuss the legal status of political parties in the construction of criminal law in Indonesia. Discussion continued with the criminal act of General
Election, as well as the accountability of Political Parties to the criminal act of the General Election.

\section{A. Political Party as a Subject of Criminal Law}

Aristoteles once stated that man is a "political animal". The meaning of that statement with regard to the condition in every society is always a lack of valuable resources, forcing people to play politics. The political meaning of Aristotle in this connection is a process of determining who gets what, when, and how. Politics is one type of human interaction involving a political party that gains and exercises power over others. If left to the individuals themselves, politics can be a bad game, with players trying to strangle each other to protect their own interests.[5] In general, what is called politics is related to various activities in a political or state system, which concerns the process of determining and implementing the goals of a country. So it can be stated that politics is a process of implementation of state goals.

With regard to the process, Ronald F. Wright has mentioned many actors involved in it.[6] One of the actors is a political party, which under the provisions of Article 1 Sub-Article 1 of Law RI Number 2 Year 2011 is defined as a national organization and formed by a group of Indonesian citizens voluntarily on the basis of equality of will and aspiration to fight for and defend the political interests of members, society, nation and state and maintaining the unity of the Unitary State of the Republic of Indonesia based on Pancasila and the 1945 Constitution of the Republic of Indonesia. The definition of Political Parties is in accordance with the meaning of sociology perspective, as Maran states that political parties are an organized group with the aim of obtaining office - governmental office. Members of the group have the same orientation, values, and ideals. In order to achieve its objectives, the steps taken by political parties are: (1) recruiting their followers, nominating their candidates, seeking funds to support their options for holding public office; (2) to formulate and promote policies that reflect public opinion. In this way political parties act as a liaison between the people they represent with the government. (3) organizing is key government institutions. Leadership positions in the legislature and its commissions are divided by parties that have the largest members in parliament.[7]

The political party as described by Miriam Budiarjo was first born in the countries of Western Europe, in parallel with the widespread notion that the people were a factor to be reckoned with and embraced in the political process. The existence of political parties developed into a liaison between the people on the one hand and the government on the other. Political parties are generally regarded as the manifestation of a modern political system or which is in the process of modernizing itself. Therefore, political parties are common in many countries. In democracies, the idea of people's participation has an ideological basis that the people are entitled to decide who will be the leader who will later determine the public policy. In order to achieve these goals, political parties are a good tool. Furthermore, Miriam Budiarjo formulates the function or role of political parties are: (1) as a means of political communication; (2) as a 
means of political socialization; (3) as a means of political recruitment.[8]

In line with Miriam, May Rudy also expressed the same view about the function or role of Political Parties. Political parties have a very important position (status) and role (role) in every democratic system. The Party plays a very strategic liaison role between government processes and citizens. Political parties provide the widest opportunity for the people to participate in political and governmental activities. Because through political parties can be realized responsible government and fight for the public interest and prevent arbitrary government action. As an organization, political parties are ideally meant to activate and mobilize the people, to represent certain interests, and to provide a compromise way for competing opinions, and to provide a means of peaceful succession of political leadership.[9]

Simply put, there is a basic element of a political party, namely human bonding and common goals. Based on the provisions of Article 2 paragraph (1) of Act 2 of 2011, the existence of human bond in a political party has been needed even since the establishment of a political party. Strictly stipulated under that Article, the establishment of a political party is constituted by thirty Indonesian citizens who are twenty-one years old or already married from each province. The presence of this element of human bonding in legal terminology is referred to as a society, which can furthermore be classified in two forms based on its objectives: profit oriented and non profit oriented. The form of association of political parties, it can be traced as a legal entity. The search for the legal entity of political parties can be known in accordance with the provisions of Article 3 of Act 2 of 2011, i.e. firmly mentioning the word legal entity. Based on the formulation of the article, it is seen that the birth of a political party as a legal entity (rechtspersoon, legal entity) because it is created or manifested through a legal process (created by legal process) in accordance with the provisions of legislation. Therefore in this case it is in line with juridical reality theory, that is, to understand the existence and capacity of legal entities as legal subjects created by law. Furthermore, as a legal subject, it can perform acts and give rights and obligations so that legal entities become person stands in judicial.[10] As a result of the Political Parties as a legal entity, it has the independence to perform legal acts. In this case even the government is also provides support to the Political Parties, as specified in Government Regulation No. 1 of 2018 is providing financial assistance.

The existence of the element of human bonding, in the perspective of criminal law has encouraged political parties to be included as a subject of criminal law. This can be traced on the basis of the development of corporate positions as legal subjects in Indonesia. In its development, the view that criminal subjects are natural human beings (natuurlijke persoon) as embodied in Article 59 of the Criminal Code (KUHP) influenced by the principle of "societas delinquere non potest" slowly began to be abandoned. Namely a legal entity can not commit a crime. If in an association there is a criminal offense, then the criminal act shall be deemed done by the board of the corporation. Despite being abandoned, the existence of
Article 59 of the Indonesian Penal Code remains in force today. As well as under the provisions of Article 103 of the Criminal Code, the existence of Article 59 of the Criminal Code is at the heart of any law in Indonesia which applies the criminal code. With regard to the existence of Article 1 paragraph (1) of the Criminal Code which in essence determines one of the forms of legality principle is stipulation of criminal acts in the Law including under Article 7 paragraph (1) of Law RI Number 12 Year 2011 which consists of Government Regulation in Lieu of Law laws and Regional Regulations, it can be determined that the construction of Indonesian criminal law subjects has always been manifest.

Subsequent developments in the formulation of the Act, a criminal offense can be done by the corporation. However, in the event of criminal liability becomes the burden of the legal entity. Corporations can be the makers of the offense, but those responsible are members of the board. The liability requirements of the board when expressly stated in the rules of the corporation itself. So in this stage it is clears that the corporation's direct criminal responsibility still has not appeared, but the gravity of criminal responsibility lies with the board. Until the peak of its development today is the corporation to be subject to criminal liability. The basis for the imposition of such liability is the law outside the Criminal Code, in the sense that the corporation as a subject of law at the same time may be subject to criminal liability is dependent on the formulation of the Act outside the Criminal Code.[11] This is understandable because it is the formulation of sanctions as under Article 10 of the Criminal Code, entirely devoted to the subject of human law alone. So that developing now, the construction of criminal law subjects in Indonesia has listed the direct responsibility of the corporation, but only limited in the law outside the Criminal Code. Therefore, in relation to the determination of whether or not a political party is qualified as a corporation and hence may be subject to criminal liability is dependent on the formulation of a law outside the Criminal Code which contains a crime. As a guide to its application, the Supreme Court has also issued Regulation of the Supreme Court of the Republic of Indonesia Number 13 of 2016 concerning the Procedures of Handling Criminal Cases by the Corporations. As in Article 3 of Minister Law (Peraturan Menteri) 13 of 2016, it is expressly stated that a criminal act by a corporation is a criminal act committed by a person based on (1) an employment relationship; or (2) other relationships. The emphasis of the formulation of Article 3 of the Minister Law is either individually or jointly acts for and on behalf of the corporation both within and outside the corporate environment. This regulation does not contain any new norms outside the Law, as affirmed in Article 23 paragraph (2) of Minister Law stating that judges may impose criminal penalties against corporations or administrators or corporations and administrators only when specified in the Act. So to determine the imposition of political parties as the subject of criminal law still refers to the provisions of the Act containing criminal acts. 


\section{B. Criminal Acts of Regional Election}

The holding of regional head elections in Indonesia is expressly stipulated in Article 62 of RI Law Number 23 Year 2014 concerning Regional Government, which pursuant to that provision shall be open to further regulation in the Law. The Act in question, respectively to the present day is the Law No. 1 of 2015 on the Determination of Government Regulation No. 1 of 2014 on the Election of Governors, Regents and Mayors Becoming Laws, Law RI No. 8 of 2015, and the Law of the Republic of Indonesia Number 10 Year 2016 About the Second Amendment to Law Number 1 Year 2015. It is because all of them are still valid and become one unit, then together can be referred to as the package of Election Law.

It is with regard to the implementation of Regional Election in Indonesia, as in the package of Election Law consists of a series of stages from the registration phase to the recapitulation stage. As already mentioned that the implementation of General Elections as well as the General Election must be truly democratic in the context of Indonesia should be able to realize the principles of direct, public, free, confidential, honest and fair general elections (law requires criminal law) including enforcement the law to fortify. Such efforts according to Sreedhar consists of preventive and repressive efforts.[12] The importance of this effort because of the Election as well as Regional Election, according to Siddhartha and Bryan C. McCannon can cause impact after.[13] Regional Election in Indonesia which designated to choose Governor, Regent, and Mayor have characteristic difference with election of Attorney as happened in America.[14] Head of Region in Indonesia function to accelerate people prosperity especially in region, while US Attorney is having function in law enforcement field. Election, as well as Regional Election according to Powel has the potential of cheating.[15] Because of this potential, then in the package of Election Law have been mentioned kinds of criminal acts in the stages of the implementation of Regional Election.

Criminal acts are always formulated in the Act, as a form of legal principle.[16] Criminal provisions in the package of the General Election Law can be briefly elaborated: (1) in the registration phase consisting of Article 1 of Law 1 Year 2015 until Article 182 of Law 1 Year 2015, together with the addition of Article 177 A Paragraph (1) of Law 10 Year 20016; (2) the stage of nomination consists of Article 180 paragraph (1) of Law 10 Year 2016 to Article 191 paragraph (2) of Law 8 of 2015; (3) the stage of the campaign consists of Article 187 paragraph (1) of Law 1 Year 2015 to Article 190 of Law 1 Year 2015, along with the addition of Article 187 A Paragraph (1) of Law Number 10 Year 2016; (4) the stage of procurement and distribution of logistics is contained in Article 190 A of Law No. 10 Year 2016; (5) the voting and counting stages shall consist of Article $178 \mathrm{~A}$ of Law Number 10 Year 2016 up to Article 182 B of Law Number 10 Year 2016; (6) the post-ballot stage consists of Article 193 paragraph (1) of Law Number 10 Year 2016 to Article 195 of Law Number 8 Year 2015; (7) the recapitulation stage consists of Article 183 of Law 1 Year 2015 to Article 198 Law 1 Year 2015; Similarly, in the package of Election Law, the criminal offenses included in the out-of-stage qualification, as set forth in Law Number 10 Year 2016 consist of: Article 187 D; Article 193 A Paragraph (1); Article 193 A Paragraph (2); Article 193 B Paragraph (1); Article 193 B Paragraph (2); Article 198 A.

With regard to the subject of criminal law, the regulation of criminal acts of the General Election of Regional Heads as consisting of 18 Articles in the package of Election Law which becomes the subject of law is a person or individual as persoonlijk. But there are also special legal subjects, with the naming in accordance with the Act, namely:

- Members of PPS, members of the PPK, members of the Regency / City KPU, and members of the Provincial KPU, Chairperson and members of the Election Commission individually or jointly (Article 177 B, Article 185 B, Article 193 paragraph $(1,2)$ Article 193 A paragraph $(1,2)$ of Law Number 10 Year 2016, Article 186 paragraph (1, 2), Article 193, Article 198 of Law 1 Year 2015;

- Chairman and members of KPPS, each KPPS, each PPS (Article 193 paragraph $(3,4,5,6,7)$ of Law No. 10 Year 2016);

- Chairman and / or member of Provincial Bawaslu (Article 193 B Paragraph (1) of Law No. 10 Year 2016);

- Chairman and / or member of District / Municipal Panwas, District Panwas (Article 194 of Law 1 Year 2015, Article 193 B Paragraph (2) of Law No. 10 Year 2016);

- Leaders of Political Parties or a coalition of Political Party Leaders (Article 191 paragraph (2) of Law 8 of 2015);

- Chairman and Secretary of Political Party at Provincial level and / or Regency / Municipal level (Article 186 A Paragraph (1) of Law No. 10 Year 2016);

- Member of a Political Party or a member of a coalition of Political Parties (Article 187 B of Law 10 Year 2016);

- Institutions (Article 187 C of Law 10 Year 2016);

- Candidate of the Head of Region or also mentioned as Candidate of Governor, Candidate of Vice Governor, Candidate of Regent, Candidate of Vice Regent, Candidate of Mayor and Candidate of Deputy Mayor (Article 187 Act 1 Year 2015, Article 189 Law 8 Year 2015);

- State Officials, State Civil Service Officials, and Village Heads or other titles / Lurah (Article 188 of Law 1 Year 2015);

- Election Organizer, or company (Article 190 A Law 10 Year 2016);

- An employer or superior (Article 182 B of Law 10 Year 2016);

- Election Monitoring Board (Article 187 D of the 10th Act of 2016);

Based on these details, political parties have been specifically named as subjects of criminal law. Therefore, with reference to the provisions of Article 23 paragraph (2) Minister Law 13 of 2016, it has become clear that the legal 
regime of Regional Election in Indonesia has recognized the Political Parties as the subject of criminal law with a series of determined crimes.

\section{Criminal Liability of Political Parties}

Criminal liability is a mechanism to determine whether a suspect or defendant is accountable for a criminal act that occurred or not. In order to punish the perpetrator, it is required that the criminal offense fulfills the elements as determined in the Act. The principle of criminal liability in criminal acts of regional head elections shall be criminal liability based on the principle of error. Simply put, the requirement for a crime to be punished is if the error in the act, whether it is intentional (with intention) and the element of negligence.

Corporate criminal liability has a different concept from criminal liability to human beings.[17] Although corporations are legal persons, there are difficulties when criminal liability is required.[18] In addition, with the corporation's position as an independent legal subject, the board may take refuge under the status of the corporation.[19] With regard to the status of Political Parties as a corporation, three types of criminal responsibility can be formulated: (1) corporate management as responsible maker and board. This idea is based on the idea that legal entities can not be criminally accounted for, because the management will always be regarded as the perpetrator of the offense. (2) The corporation as responsible maker and board. This model realizes that the corporation as the maker but for the responsibility is left to the board. (3) The corporation as the maker and also as the responsible. This model takes into account the development of the corporation itself, because it is not enough just to set the board as responsible.[20] With regard to the determination of criminal responsibility there are also five theories: (1) identification theory, commonly called direct corporate criminal liability or corporate criminal liability directly. According to this theory, the corporation may commit a number of offenses directly through a board that is closely related to the corporation, acting for and on behalf of the corporation so as to be seen as the corporation itself. They are not a substitute and therefore, corporal responsibility is not a personal accountability;[21] (2) the theory of strict liability, which is defined as strict liability under the law. So corporate responsibility is solely based on the sound of the Law regardless of who makes mistakes. In strict liability the element of error does not need to be proven. There are two main purposes of imposing strict liability. First, it is to protect the public from dangerous actions by creating a higher standard of care. Second, to regulate quasi-criminal activities in as efficient manner possible;[21] (3) vicarious liability theory, a substitute accountable doctrine that places greater emphasis on corporate accountability as the agent of the corporation's actions. This teaching departs from the doctrine of superior responders, based on the employment principle and the delegation principle. This doctrine is the exception of individual liability embraced in criminal law based on the aditarian nemo punitur pro alieno delicto (no one is punished for the actions of others). Thus when speaking vicarious liability in it contains a principle of substitute liability for criminal acts committed by others; (4) the theory of aggregation, which states that criminal responsibility can be imposed on corporations if the act is committed by a number of people who meet the elements of offense which are inter-related to each other and not stand alone; (5) corporate cultural theory of models or models of work culture. This teaching focuses on explicit and implicit corporate policies that affect how the corporation works. Corporations may be criminally liable if a person's conduct has a rational basis that the corporation authorizes or permits the act to take place.[22]

As already mentioned, in the package of Election Law has recognized the Political Parties as the subject of criminal law or concretely as a corporation. However, the imposition of criminal liability as in the package of Owners Act is not directly to the Political Parties themselves. This matter can be observed from the Articles in the package of Election Law which contains the criminal acts of Political Parties: (1) Article 191 paragraph (2) of Law 8 of 2015 imposition of criminal responsibility to Leaders of Political Parties or joint Leaders of Political Parties; (2) of Article 186 A Paragraph (1) of Law Number 10 Year 2016 imposing its criminal responsibility to the Chairperson and Secretary of Political Party at Provincial level and / or Regency / City level; (3) of Article 187 B of Law Number 10 Year 2016 the imposition of criminal responsibility shall be imposed on a member of a Political Party or a member of a coalition of Political Parties. Seeing the construction in the Act, the criminal liability of political parties for the criminal act of General Election is in line with the theory of vicarious liability. This means that the package of Election Law as the basis for regulating the criminal act of General Election which has also placed the Political Parties as a corporation, apparently still has not applied the theory of identification. The enforcement of criminal sanctions is intended for human beings, and not against corporations.

\section{CONCLUSION}

In line with the importance of the function of general election of head of region to political party and importance of role of political party itself, hence has been arranged kinds of criminal act of $\mathrm{R}$ which put Political Party as one of subject of criminal law. The arrangement shows the progress of democracy in Indonesia, in the sense that the implementation of Regional Election as part of the electoral law regime has been guarded so as to truly embody the principle of direct, public, free, confidential, honest and fair. The recognition of political parties as one of the subjects of criminal law has not been run linearly with criminal responsibility, it is stated that criminal liability to the new Political Parties adopts the theory of substitute liability. Political parties as a legal entity that can perform legal acts may even commit a criminal offense, but those who can be convicted are human beings, namely: Chairman, Chairperson and Secretary of Political Party at Provincial level and / or Regency / City level, members. This can be said to be ineffective, therefore a regulation which also requires direct criminal responsibility for political parties is required. Given also sanctions against political parties directly in Indonesia is currently only found in the absolute competence of the 
Constitutional Court, namely in the case of the dissolution of Political Parties.

\section{ACKNOWLEDGMENT}

With regard to this research, thanks to the Universitas Negari Surabaya, especially to Dean of the Faculty of Social Sciences and Law. Thank you also to colleagues Lecturer at the Faculty of Social Sciences and Law, Universitas Negeri Surabaya

\section{REFERENCES}

[1] P. M. Hadjon, Pengantar Hukum Administrasi Indonesia. Yogyakarta: Gadjah Mada University Press, 2002.

[2] J. Deckert, M. Myagkov, and P. C. Ordeshook, "Benford's Law and the detection of election fraud," Polit. Anal., 2011.

[3] A. Prasetia, "https://news.detik.com/berita/d-3479819/ini-171daerah-yang-gelar-pilkada-serentak-27-juni-2018," 2017.

[4] P. M. Marzuki, Penelitian Hukum. Jakarta: Prenadamedia Group, 2016.

[5] H. Laswell, A Study of Power. Illionis: The Free Press, 1950.

[6] R. F. Wright, "How Prosecutor Elections Fail Us," Ohio State J. Crim. Law, vol. 6, no. 1913, pp. 581-610, 2009.

[7] R. R. Maran, Pengantar Sosiologi Politik. Jakarta: Rineka Cipta, 2002.

[8] M. Budiarjo, Dasar-dasar Ilmu Politik. Jakarta: Gramedia, 1986.

[9] T. M. Rudy, Pengantar Ilmu Politik. Bandung: Refika Aditama, 2003.

[10] R. Usman, Dimensi Hukum Perseroan Terbatas. Bandung:
Alumni, 2004.

[11] D. P. Muladi, Pertanggungjawaban Pidana Korporasi. Jakarta: Kencana, 2012.

[12] K. S. Rao, "Journal of the indian law institute," vol. 43, no. 2, 2001.

[13] S. Bandyopadhyay and B. C. Mccannon, "The effect of the election of prosecutors on criminal trials," no. October 2012, pp. 141-156, 2014

[14] M. J. Ellis, "The Origins of the Elected Prosecutor," pp. 15281569,2012

[15] G. B. Powell, "Election laws and representative governments: Beyond votes and seats," Br. J. Polit. Sci., 2006.

[16] "Fraud act 2006," Criminal Law Review, 2007.

[17] B. Lewis and S. Woodward, "Corporate criminal liability," American Criminal Law Review. 2014.

[18] V. S. Khanna, "Corporate criminal liability: What purpose does it serve?," Harv. Law Rev., 1996.

[19] G. Ferguson, "Criminal Liability and Criminal Defenses," in International Encyclopedia of the Social \& Behavioral Sciences: Second Edition, 2015

[20] Setiyono, Kejahatan Korporasi: Analisis Viktimologi dan Pertanggungjawaban Korporasi dalam Hukum Pidana Indonesia. Malang: Bayu Media, 2005.

[21] C. Elliott and F. Quinn, "Strict liability," Crim. Law, 2012.

[22] A. \& M. E. Pinto, Corporate Criminal Liability. London: Sweet and Maxwell, 2003. 